\title{
Phenology and potential reproduction of turi (Sesbania grandiflora) at Cibinong, Bogor, Indonesia
}

\author{
DIDA SYAMSUWIDA ${ }^{\vee}$, AAM AMINAH \\ Forest Tree Seed Technology Research and Development Centre, Jl. Pakuan Ciheuleut PO BOX 105, Bogor 16129, West Java, Indonesia. \\ Tel./fax: +62-251-8327768, "email:dida_syam@yahoo.co.id
}

Manuscript received: 2 May 2019. Revision accepted: 10 January 2020.

\begin{abstract}
Syamsuwida D, Aminah A. 2020. Phenology and potential reproduction of turi (Sesbania grandiflora) at Cibinong, Bogor, Indonesia. Nusantara Bioscience 12: 13-20. Turi (Sesbania grandiflora (L.) Pers.) is one of a prospectus energy woody species to be developed in establishing renewable energy base forest plantation. The development of this species cannot be separated from the basic information of its reproductive biology. The study was aimed to evaluate flowering phenology and reproductive potency of $S$. grandiflora so that information could be elaborated to estimate the fruit production potential produced. The research method was carried out by direct observation of samples of flowering trees. Data were analyzed descriptively. The number of tree samples observed for flower and fruit development and reproductive success of 10 trees, from each tree were observed three flowering branches distinguished from the west and east branches. The results showed that $S$. grandiflora did not experience generative bud dormancy so that flower initiation was thought to occur throughout the year and could flower and bear fruit throughout the year. S. grandiflora at the observation location has a flowering-fruiting development cycle of about 3-4 months which begins with the emergence of generative bud at the time of the observation in April and developed into flower shoot in the same month. Blooming flower (anthesis) in May, develop into young fruit in June. Mature fruits can be harvested in June-July. The reproductive potency of S. grandiflora was low with a value of fruit set (fruit/flower ratio) at the eastern and western branches were $19 \% \pm 0.07$ and $17 \% \pm 0.06$ and seed set (seed/ovule ratio) of $87 \% \pm 0.12$ and $83 \% \pm 0.16$, respectively. Reproductive success was $18 \% \pm 0.07$ for the eastern branches and $17 \% \pm 0.05$ for the western branches. Most reproductive variables of $S$. grandiflora did not show a significant difference between the eastern and western branches $(\mathrm{P}>0.05)$, except for fruit number $(\mathrm{P}<0.05)$.
\end{abstract}

Keywords: Flower-fruit development, reproductive success, seed, Sesbania grandiflora, turi

\section{INTRODUCTION}

Turi (Sesbania grandiflora (L) Pers.) belongs to Leguminosae. As an energy wood species, S. grandiflora has a high heat value $(5.624,04 \mathrm{cal} / \mathrm{g}$ ) (Koeslulat et al. 2016) and high adaptability to environmental conditions. In an effort to support the development of sustainable energy timber forests to meet the needs of the community, the provision of quality seeds is needed. Seeds for planting programs are required to be available in adequate quantities and quality continuously. Guarantees for the availability of seeds in a sustainable manner require some information about flowering and fruiting, including the phenology of flowering and reproductive systems. Understanding of the flowering and fruiting phenology can be basic knowledge for improving the quality and quantity of seeds by predicting the exact time of harvest and production of seeds every year. While, seed or fruit production could also be estimated through measuring reproductive potential.

The study of phenology is truly related to climate and non-climatic environmental factors. Climate change is shifting species' distribution and phenology (Brown et al. 2016). Extreme climate deviations have an impact on changes in plant flowering phenology. Ashari et al. (2014) stated that due to high rainfall increased, the flowering of citrus (Citrus nobilis var Microcarpa) was changed from usually three times to six times in a year, however, it turned out became a less fruit produced. This might be happened due to the continuous rainfall that causes moisture and high groundwater content so that the water content towards the flower will be excessive and causes loss. Kimball et al. (2014) use phenology and long-term weather records to assess how sensitive three major species (Diapensia lapponica, Carex bigelowii and Vaccinium vitis-idaea) of these alpine ecosystems may be to ongoing regional warming trends. Cardoso et al. (2019) found differences in the rate of occurrence and concentration of phenological phases, suggesting that habitat changes caused by succession and species turnover are additional factors affecting phenological patterns in tropical forests.

The flowering and fruiting phenology of $S$. grandiflora has not yet known clearly. However, it is reported that the flowering period of the $S$. grandiflora occurs 2-3 months and initiation is suspected to occur throughout the year (Putri et al. 2015). This information needs to be proven by conducting phenological observations which include the reproductive cycle, initiation of flowering and reproductive success. The aim of the study was to evaluate the flowering and fruiting phenology and potential reproduction of $S$. grandiflora in terms to obtain the inferences of the flowering development and reproductive success. 


\section{MATERIALS AND METHODS}

\section{Study area}

The location of $S$. grandiflora phenology observations in Pabuaran Village, Cibinong Sub-district, Bogor District, West Java, Indonesia (Figure 1). The geographical location of the research location is $106^{\circ} 48^{\prime} 02.40^{\prime \prime} \mathrm{E}$ and $6^{\circ} 28^{\prime} 26.2$ 'S with an altitude of $132 \mathrm{~m}$ above sea level and climate type A. Temperatures range from $23-30^{\circ} \mathrm{C}$ and humidity of $80 \%$ (BMKG 2013).

The research was conducted from February to December 2013. The research material consisted of 10 sample trees. The equipment used was a camera, stationery, microscope and kit tools.

\section{Procedures}

Observation of the flower and fruit development phenology (Owens et al. 1991)

Of the 10 trees observed, five branches containing generative buds on each tree were marked with color ribbon, both at branches in the East and West. Three flowers that grow on each branch are marked with a plastic label to be observed.

The development of flowering and fruiting per branch were observed starting from the appearance of flower buds, flowers bloom, flower fall, young fruit to mature fruit. Every change in flower and fruit structures was observed by recording the time (the date and period required for each change), the dimensions, shapes, and colors (Owens et al.1991).
Climate data obtained from BMKG-Bogor (2013) recorded during observations included data on temperature, rainfall, humidity, length of irradiation and number of rainy days.

Measurement of reproductive success

The number of samples was 60 units (10 trees x 3 branches $\mathrm{x} 2$ sun direction position). The parameters measured are the number of flowers and fruits per branch, the number of ovules per flower, the number of seeds per fruit.

The reproductive success measured is pre-emergent reproductive success, which is the proportion of ovules that are successfully fertilized and develop into viable seeds.

Reproductive success (KRSP) is calculated in a way (Weins et al. 1987) as follows:

$$
\begin{aligned}
& \text { Ratio of fruit/flower ratio }=\frac{\text { Number of fruit }}{\text { Number of flowers }} \\
& \text { Ratio of Seed/ovule ratio }=\frac{\text { number of seeds }}{\text { number of ovules }}
\end{aligned}
$$

Reproduction Success $($ PERS $)=$ Fruit/flower ratio $\mathrm{x}$ Seed/ovule ratio

\section{Data analysis}

Phenology and flowering development phenology data were analyzed descriptively, while reproductive success data were tested by paired T-tests to see differences between reproductive variables in the branches of the west and east.
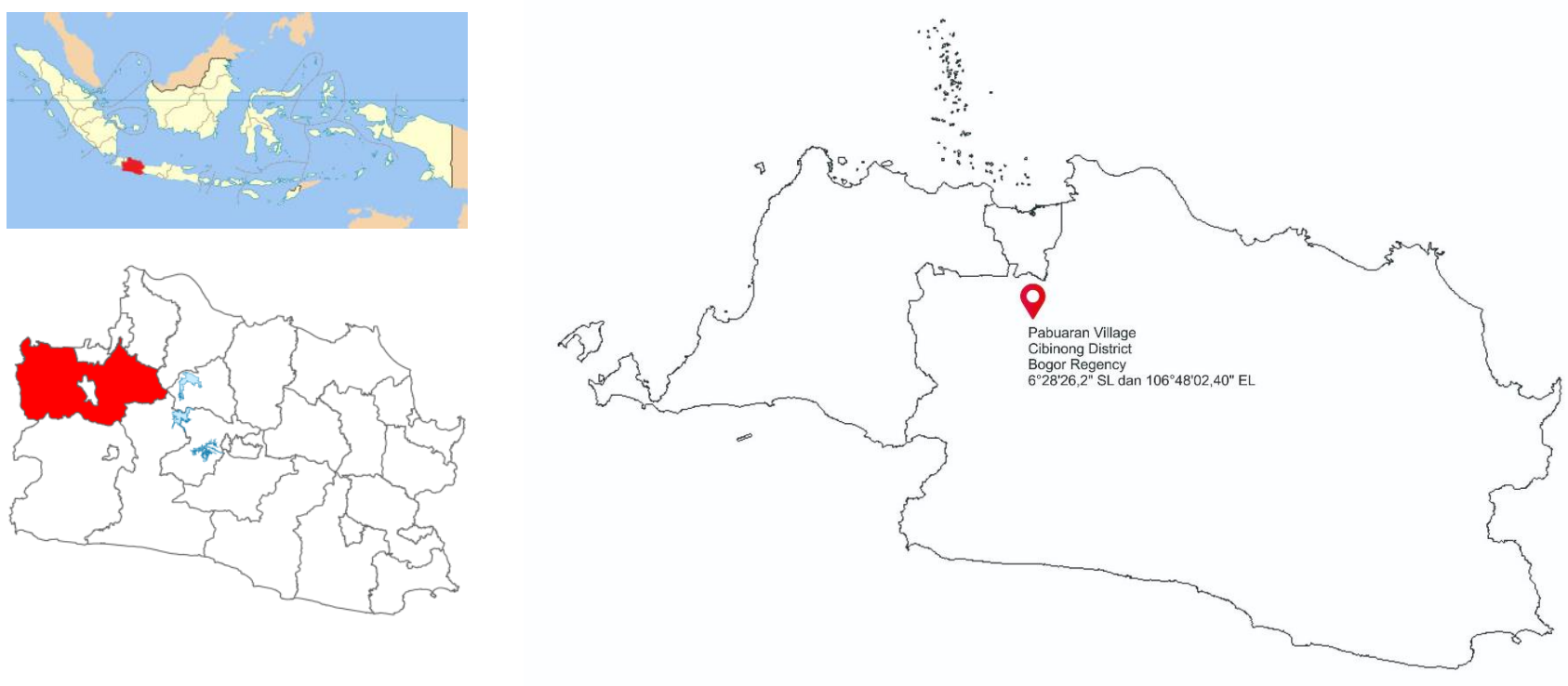

Figure 1. Location of Sesbania grandiflora phenology observations in Pabuaran Village, Cibinong Sub-district, Bogor District, West Java, Indonesia 


\section{RESULTS AND DISCUSSION}

\section{Phenology of flower and fruit development}

The periodicity or time occurrence of each phase of change in the development of flowering and fruiting of $S$. grandiflora observed in Cibinong-Bogor is presented in Table 1.

Flowering observations begin in early April. At the time of observation in one tree, flowering structures have been seen starting from the generative phase to blooming flowers, as well as young fruits and mature fruits. The process of development of flowering and fruiting (Figure 2) starts from the emergence of generative buds that come out from the end of a branch (terminal) in the form of a small bend, then develops into a shoot of flowers. The flowering process of the $S$. grandiflora takes place continuously without any delay in bud dormancy, so that flower initiation can be expected to occur throughout the year and enable it to be flowers and fruits in around year too. However, more flowers and fruits usually occur in the dry months (June-August). Climatic conditions during flowering and fruiting of S. grandiflora in 2013 (BMKG 2013) can be seen in Figure 3.

The developmental phase of flowering is from generative buds, small flower shoots to large flower shoot observed during April. In April the ambient temperature was quite warm (an average of $26.4^{\circ} \mathrm{C}$ ) with relatively low air humidity $(85 \%)$ and the lowest rainfall intensity since January $(216 \mathrm{~mm} / \mathrm{month})$, but with a relatively high number of rainy days that is 25 days. The flowering phase blooms until the ovarian enlargement enters May with climatic conditions which are relatively stable as in April, except for an increase in rainfall intensity reaching 399.3 $\mathrm{mm} / \mathrm{month}$, but the number of rainy days decreases $(22$ days). During the fruiting phase from the development of young fruit to maturation, it occurs in June and early July. In June there was a slight increase in temperature, but fell again in July, reaching an average temperature of $25.4^{\circ} \mathrm{C}$.
This decrease was followed by a decrease in air humidity and length of irradiation, but there was an increase in rainfall intensity and the number of rainy days (Figure 3 ).

\section{Reproductive success}

The calculation results of $S$. grandiflora reproduction parameters such as the number of flowers per branch, number of fruits per branch, number of ovules per flower, number of seeds per fruit, fruit set $(\mathrm{Fr} / \mathrm{Fl})$, seed set $(\mathrm{S} / \mathrm{O})$ and reproductive success (PERS) presented in Table 2.

Overall the reproductive success of $S$. grandiflora is very low such as Acacia leucophloea and Albizia procera which are $34 \%$ and $35 \%$ respectively (Syamsuwida et al. 2011). The ratio of fruit to flower or fruit set ranges from $12-24 \%$. However. the ratio of ovules into seeds or seed sets is quite high. between 71-99\%. Reproductive success value (PERS) was obtained with a range of 11-23\% (Table $3)$. Thus. the proportion of ovules that were successfully fertilized and developed into viable seeds was an average of $17 \%$.

The results of statistical tests showed that all reproductive variables in the Eastern branch were not different from the Western part except the number of fruit per branch (Table 3 ).

\section{Discussion \\ Phenology of flower and fruit development}

The success of a plant's reproductive process depends on its ability to go beyond developmental stages which begin with the initiation of flower buds and end with the maturity of the fruit and seeds. Failure in one of these stages of development can result in a decline in seed production as the end product (Pramono et al. 2017). Flowering observations begin in early April. At the time of observation, flowering structures have been seen starting from the generative phase to blooming flowers. as well as young fruits and mature fruits.

Table 1. Period and time of development of flowering and fruiting of Sesbania grandiflora at Cibinong, Bogor, Indonesia research plot

\begin{tabular}{|c|c|c|c|}
\hline $\begin{array}{l}\text { Stage of reproductive } \\
\text { development }\end{array}$ & $\begin{array}{r}\text { Period } \\
\text { (days) }\end{array}$ & Month & Information \\
\hline Flower initiation & - & - & Not observed \\
\hline Generative buds & $10-12$ & April & Occurs in the terminal part, rounded shape \\
\hline Small flower shoots & $7-9$ & April & $\begin{array}{l}\text { Generative bud develop to form a pair of small flower shoot }(3-6 \times 6-16 \mathrm{~mm}) \text {, green } \\
\text { petals }\end{array}$ \\
\hline Large flower shoots & $3-5$ & April & Enlarged shoot $(6-11 \times 17-35 \mathrm{~mm})$, green petals \\
\hline White flower shoots & $1-2$ & April & Shoot larger (17-22 x 41-71 mm), white petals \\
\hline Flowers bloom & $1-2$ & April & The crown (corolla) is slightly broken \\
\hline Flowers wither & $1-2$ & April & $\begin{array}{l}\text { Crown strands (petals) wither and do not fall indicating pollination has occurred which } \\
\text { will be followed by ovarian development }\end{array}$ \\
\hline Ovaries enlarge & $1-2$ & April & Pistil stalk (Stylus) extends, the tip swells \\
\hline Young fruits & $12-14$ & Mei & $\begin{array}{l}\text { The structure of the pods is clear, the shape of the pod is straight, the seeds are not yet } \\
\text { clear, the color is bright green }\end{array}$ \\
\hline Mature fruits & $21-28$ & Juni-July & The structure of the pods is clear, larger in size, seedy, yellowish-green \\
\hline
\end{tabular}




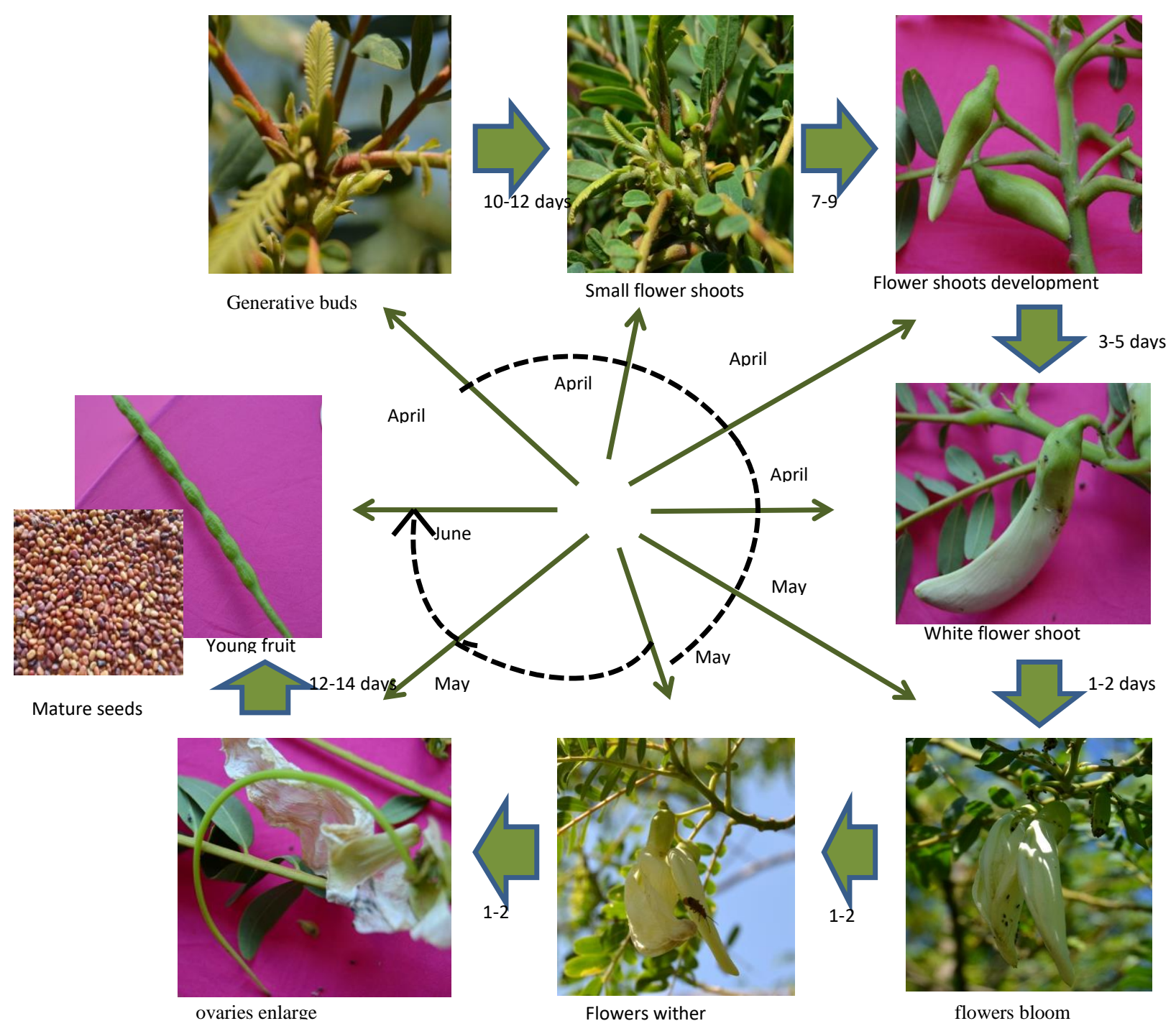

Figure 2. Flowering and fruiting development cycle of Sesbania grandiflora at Cibinong, Bogor, Indonesia research plot (Table 1).
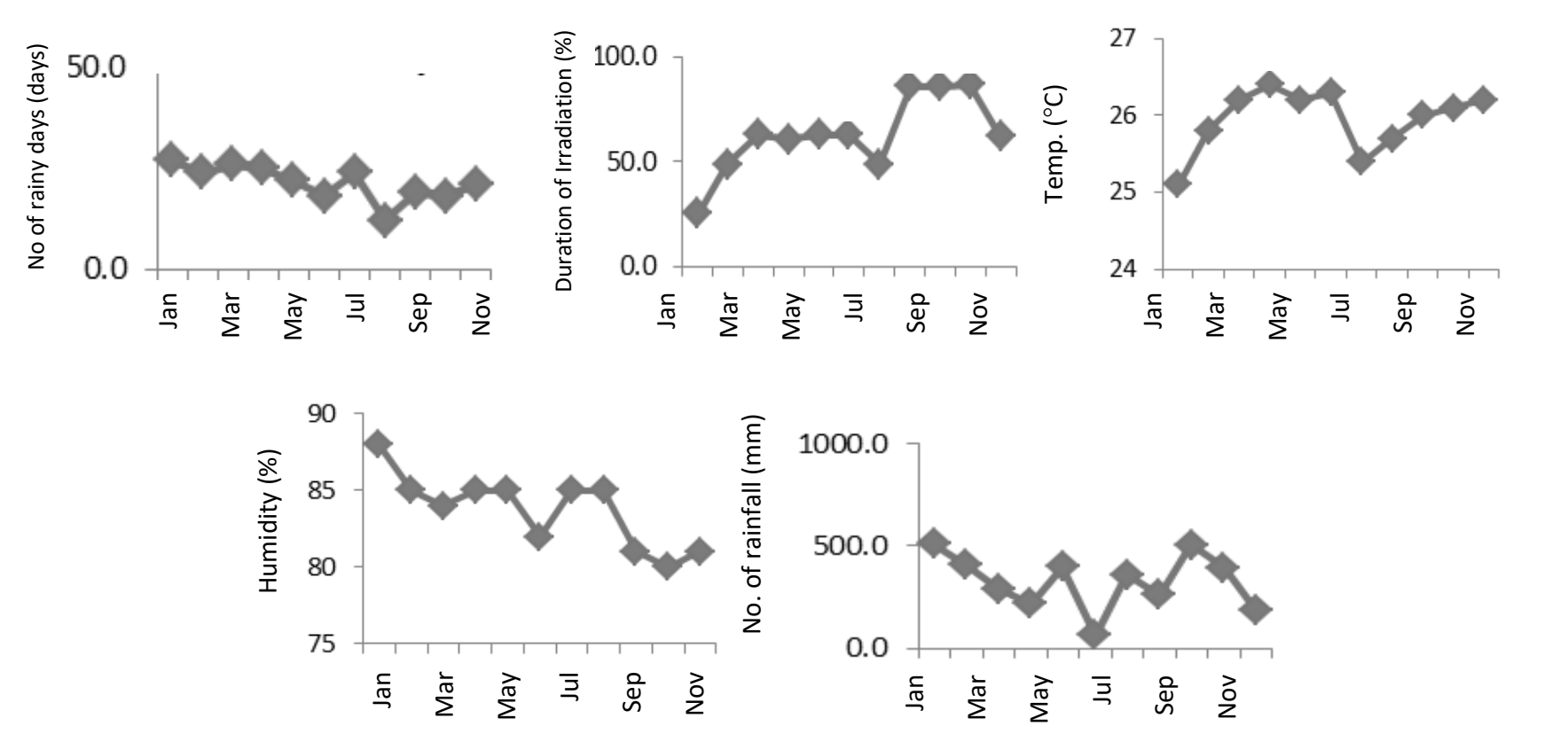

Figure 3. Climate conditions in 2013 in Bogor (BMKG 2013) 
Table 2. The average results of measurements of Sesbania grandiflora reproduction parameters in the Eastern (E) and Western (W) branches

\begin{tabular}{|c|c|c|c|c|c|c|c|c|}
\hline No. & $\mathbf{n}$ & $\begin{array}{c}\sum \text { flower/ } \\
\text { branch }\end{array}$ & $\sum_{\text {branch }}$ fruit/ & $\sum_{\text {flower }}$ ovule/ & $\sum_{\text {fruit }}$ seed/ & $\begin{array}{c}\text { Fruit set } \\
\text { (Fr/Fl) }\end{array}$ & $\begin{array}{c}\text { Seed set } \\
(\mathrm{S} / \mathrm{O})\end{array}$ & PERS \\
\hline E.1 & 3 & $8.67 \pm 0.58$ & $1.67 \pm 0.58$ & $31.67 \pm 1.15$ & $30.67 \pm 2.08$ & $0.19 \pm 0.06$ & $0.97 \pm 0.03$ & $0.18 \pm 0.06$ \\
\hline W.1 & 3 & $5.00 \pm 1.00$ & $1.33 \pm 0.58$ & $28.33 \pm 1.53$ & $28.00 \pm 2.00$ & $0.26 \pm 0.07$ & $0.99 \pm 0.02$ & $0.26 \pm 0.07$ \\
\hline E.2 & 3 & $8.67 \pm 1.15$ & $1.33 \pm 0.58$ & $25.67 \pm 3.06$ & $24.33 \pm 2.31$ & $0.15 \pm 0.04$ & $0.95 \pm 004$ & $0.14 \pm 0.04$ \\
\hline W.2 & 3 & $6.00 \pm 3.46$ & $1.00 \pm 0.00$ & $24.33 \pm 0.58$ & $23.33 \pm 2.31$ & $0.25 \pm 0.22$ & $0.96 \pm 0.04$ & $0.24 \pm 0.21$ \\
\hline E. 3 & 3 & $11.33 \pm 2.89$ & $1.67 \pm 0.58$ & $15.33 \pm 9.60$ & $23.33 \pm 0.58$ & $0.09 \pm 0.03$ & $0.87 \pm 0.05$ & $0.08 \pm 0.02$ \\
\hline W.3 & 3 & $4.67 \pm 2.52$ & $0.67 \pm 0.58$ & $11.33 \pm 9.87$ & $13.33 \pm 3.51$ & $0.11 \pm 0.10$ & $0.65 \pm 0.56$ & $0.11 \pm 0.10$ \\
\hline E. 4 & 3 & $8.33 \pm 2.89$ & $1.67 \pm 0.58$ & $32.67 \pm 0.58$ & $30.00 \pm 1.00$ & $0.20 \pm 0.00$ & $0.92 \pm 0.03$ & $0.18 \pm 0.01$ \\
\hline W.4 & 3 & $6.33 \pm 1.53$ & $1.33 \pm 0.58$ & $30.67 \pm 2.08$ & $29.00 \pm 2.00$ & $0.21 \pm 0.04$ & $0.95 \pm 0.05$ & $0.20 \pm 0.05$ \\
\hline E. 5 & 3 & $7.33 \pm 0.58$ & $1.00 \pm 0.00$ & $39.67 \pm 0.58$ & $38.67 \pm 1.53$ & $0.14 \pm 0.01$ & $0.97 \pm 0.03$ & $0.13 \pm 0.01$ \\
\hline W.5 & 3 & $5.33 \pm 2.52$ & $0.67 \pm 0.58$ & $22.67 \pm 19.66$ & $21.67 \pm 18.77$ & $0.11 \pm 0.10$ & $0.64 \pm 0.55$ & $0.10 \pm 0.10$ \\
\hline E.6 & 3 & $12.00 \pm 2.00$ & $2.00 \pm 0.00$ & $15.67 \pm 0.58$ & $14.67 \pm 1.53$ & $0.17 \pm 0.03$ & $0.93 \pm 0.07$ & $0.16 \pm 0.04$ \\
\hline W.6 & 3 & $7.00 \pm 2.65$ & $1.33 \pm 0.58$ & $14.33 \pm 2.31$ & $13.33 \pm 1.53$ & $0.19 \pm 0.02$ & $0.94 \pm 0.06$ & $0.18 \pm 0.02$ \\
\hline E.7 & 3 & $10.33 \pm 3.06$ & $1.67 \pm 0.58$ & $15.00 \pm 2.00$ & $13.67 \pm 1.15$ & $0.16 \pm 0.02$ & $0.92 \pm 0.07$ & $0.15 \pm 0.03$ \\
\hline W.7 & 3 & $10.33 \pm 4.73$ & $1.30 \pm 0.58$ & $15.33 \pm 2.08$ & $14.33 \pm 1.15$ & $0.14 \pm 0.06$ & $0.94 \pm 0.06$ & $0.13 \pm 0.06$ \\
\hline E. 8 & 3 & $2.00 \pm 0.00$ & $0.67 \pm 0.58$ & $19.33 \pm 16.86$ & $18.67 \pm 16.20$ & $0.33 \pm 0.29$ & $0.65 \pm 0.56$ & $0.32 \pm 0.28$ \\
\hline W.8 & 3 & $5.67 \pm 4.04$ & $1.33 \pm 1.15$ & $20.00 \pm 17.32$ & $19.00 \pm 16.46$ & $0.20 \pm 0.20$ & $0.63 \pm 0.55$ & $0.19 \pm 0.19$ \\
\hline E.9 & 3 & $4.00 \pm 2.00$ & $1.00 \pm 0.00$ & $16.00 \pm 13.86$ & $15.67 \pm 13.58$ & $0.28 \pm 0.25$ & $0.65 \pm 0.57$ & $0.27 \pm 0.25$ \\
\hline W.9 & 3 & $4.00 \pm 2.00$ & $0.67 \pm 0.58$ & $14.00 \pm 12.17$ & $13.33 \pm 11.55$ & $0.14 \pm 0.13$ & $0.64 \pm 0.55$ & $0.13 \pm 0.12$ \\
\hline E.10 & 3 & $10.67 \pm 2.08$ & $1.67 \pm 0.58$ & $13.67 \pm 1.15$ & $12.33 \pm 1.15$ & $0.15 \pm 0.04$ & $0.90 \pm 0.08$ & $0.14 \pm 0.05$ \\
\hline W.10 & 3 & $10.67 \pm 5.03$ & $1.33 \pm 0.08$ & $12.67 \pm 0.58$ & $12.33 \pm 1.15$ & $0.13 \pm 0.03$ & $0.97 \pm 0.05$ & $0.13 \pm 0.03$ \\
\hline \multicolumn{2}{|c|}{ Average } & $7.42 \pm 2.85$ & $1.25 \pm 0.39$ & $19.86 \pm 7.92$ & $20.91 \pm 8.11$ & $0.18 \pm 0.06$ & $0.85 \pm 0.14$ & $0.17 \pm 0.06$ \\
\hline \multicolumn{2}{|c|}{ Western branch average } & $8.33 \pm 3.20$ & $1.40 \pm 0.41$ & $21.20 \pm 9.18$ & $22.47 \pm 9.29$ & $0.19 \pm 0.07$ & $0.87 \pm 0.12$ & $0.18 \pm 0.07$ \\
\hline \multicolumn{2}{|c|}{ East branch average } & $6.50 \pm 2.27$ & $1.10 \pm 0.32$ & $18.53 \pm 6.66$ & $19.37 \pm 6.47$ & $0.17 \pm 0.06$ & $0.83 \pm 0.16$ & $0.17 \pm 0.05$ \\
\hline
\end{tabular}

Table 3. Paired t-test of the effect of sun direction on Sesbania grandiflora reproduction variables

\begin{tabular}{lll}
\hline Reproductive variables & East & West \\
\hline Number of flowers & $8.33 \mathrm{a}$ & $6.50 \mathrm{a}$ \\
Number of fruits & $1.44 \mathrm{a}$ & $1.09 \mathrm{~b}$ \\
Number of ovules & $22.46 \mathrm{a}$ & $19.35 \mathrm{a}$ \\
Number of seeds & $22.20 \mathrm{a}$ & $18.70 \mathrm{a}$ \\
Fruit set & $0.18 \mathrm{a}$ & $0.17 \mathrm{a}$ \\
Seed set & $0.87 \mathrm{a}$ & $0.83 \mathrm{a}$ \\
PERS & $0.17 \mathrm{a}$ & $0.16 \mathrm{a}$ \\
\hline
\end{tabular}

Note: The average value followed by the same letter indicates no significantly different at the level of $\alpha: 0.05$

Primordia of flowers that have been initiated will develop into flower shoots that take about 10-12 days (Table 2). Flower buds develop into small flower shoots that are green. Enlarged flower shoots ranging from green to large white shoots and soon become blooming flowers take between 12-18 days. When the petal part (flower crown strands) wither. it will show the stalk (stylus) elongated and the stigma (stigma) enlarged. At this time the locus where the seeds are located is invisible. The next fruit development begins with an enlarged ovary that can be observed more than 2-4 days after the flower blooms. The development of young fruit occurs 13-16 days after ovarian enlargement. The fruits reach the harvest ready for germinating takes 35-46 days or one to one and a half months after the blooming flowers are marked with brownish pod color. Overall the flowering and fruiting process from the generative bud phase to the ripe fruit takes 56-74 days or 3-3.5 months. This development process requires a relatively short time compared to other types of energy wood such as Calliandra callothyrsus (4-5 months). Acacia auriculiformis (7-8 months) or Albizia procera (7-8 months) (Syamsuwida et al. 2014a); Syamsuwida et al. 2015; Dharmawati et al. 2016). Like other species that have short reproductive cycles (C.callothyrsus), S. grandiflora do not appear to have bud dormancy. Thus, in one branch, there will be a generative bud phase to the mature fruit. However, it has not been known how many times a series of developmental stages of flowering occurs in one branch until the branch is no longer productive.

The process of flowering and fruiting development observed (Figure 1) starts from the emergence of generative buds that come out from the end of the branch (terminal) in the form of a small bend, then develops into a flower shoot. Flower shoots develop into green flower shoots. Then it develops into a white flower crown (petal) which the crown is still closed and finally, a blooming flower is white. If pollination occurs, then the petal will wither and the stylus will elongate while the ovary is swollen. The ovary gets bigger and bigger and forms elongated fruit, straight in bright green shape, then becomes an adult pod with a larger size. Fruit pods are indehiscence, that is, when the pod coat is brownish yellow, which indicates the fruit's maturity, the seeds remain attached to the pod coat. This type of fruit allows 
fruit to be harvested when it is overcooked (over matured) without losing the seeds in it.

Flowering and fruiting of $S$. grandiflora in several places in West Java and West Bali were observed to show similar patterns. as well as flowering time and periodicity of flowering to fruiting. The flowering process of $S$. grandiflora takes place continuously without any delay in bud dormancy. However, more flowering and fruiting usually occur in the dry months (June-August). According to Fauzi et al. (2017), environmental factors such as temperature and light intensity strongly influences in triggering the flowering.

Observing from the development phase of flowering and fruiting of $S$. grandiflora which is relatively short (3-4 months) and occurs in the months with relatively stable climatic conditions (no extreme climate changes during April-May) in Bogor, it seems the flower development phase is not affected by climatic conditions. This matter understandable regarding the climate that is happening in tropical regions which have two different seasons (dry and rainy), so that the flowering process is not interrupted or stopped due to the influence of change climate (Syamsuwida et al. 2014).

However, when entering the fruit ripening period, there is an increase in temperature, a decrease in humidity and rainfall intensity (Figure 3). Ariyanti's (2018) research results show that temperature and humidity have an effect on durian fruit production because the increase in value up to a certain point is needed by flower primordia to form flower buds and carry out flowering processes. While rainfall does not have a linear correlation with durian fruit production because the higher the rainfall, the fruit production will decrease. This happens due to a high rainfall that can abort the flower so that the production of the fruit is very low or even does not produce at all (Ruminta 2015; Sarvina and Sari 2017).

Air temperature is an important environmental factor because it affects plant growth and plays a role in almost all growth processes (Fauzi et al. 2017). Temperature is an aspect of intensity of heat energy. The aspect of heat energy capacity is also important but the temperature or energy intensity aspects of the influence are more direct influencing (Wiraatmaja 2017). At low temperatures (minimum) plant growth becomes slow and even stops, because enzymatic activity is controlled by temperature. Low temperatures in most plants cause damage to stems, young leaves, flower buds and fruit (Wiraatmaja. 2017). In this study, the temperature at the time of flower and fruit development is in good condition $\left(25^{\circ} \mathrm{C}-26^{\circ} \mathrm{C}\right)$.

In connection to the duration of irradiation or light intensity, there was an increase in July (90\% irradiation duration) where the maturation of the fruit of $S$. grandiflora takes place. Solar radiation captured by chlorophyll in plants that have leaf green is energy in the photosynthesis process. The photosynthesis results are the main ingredient in the growth and production of food crops. In addition to increasing the rate of photosynthesis, increased sunlight usually speeds up the process of flowering and fruiting (Sunu and Wartoyo 2006). In this process, light energy is needed for the continuation of unification of $\mathrm{CO}_{2}$ and water to form carbohydrates and carbohydrates are needed in fruit formation. Another case shows that at clear skies, heliotropism of the sunflower head leaves throughout the day could result in an average increase of $9.5 \%$ in photosynthesis compared to the optimum arrangement of fixed leaves, and $23 \%$ increase to a (hemi-) spherical distribution (Kutschera and Briggs 2016).

Water is a very important factor in crop production. The amount of excess water in the soil will change various chemical and biological processes that limit the amount of oxygen and increase the formation of compounds that are harmful to plant roots. Heavy rainfall can disrupt flowering and pollination. According to Ariyanti (2018), the intensity of rainfall must be sufficient, so that the harvested fruit does not experience decay. If not, there will be loss of flowers, dead stalks, and fruit rot. In addition, there is also a correlation between excessive precipitation and high rate mortality of honey bees as insect pollinators (Switaneck et al. 2017) which causing low pollination and thus decreasing fertilization process that makes limitation on fruit produced.

\section{Reproductive success}

The reproductive success was $17 \%$ on average. This value was achieved from the multiplication of fruit set (18\%) and seed set $(85 \%)$. The reproductive success of $S$. grandiflora is lower than other species of forest trees.

Meanwhile, flowering on branches in the East produces higher reproductive parameter values than in the West. However, this difference still needs to be tested for its significance. Fruit set on the Eastern branch is $19 \%$ on average and $17 \%$ on the West. The value of the seed set in the East also shows a higher number $(87 \%)$ so that the PERS value is also higher that is an average of $18 \%$. However, the differences are not showing significant, this might happen when the irradiation intensity in the eastern of the canopy part is more or less similar to the western. Likely to the species of kemenyan (Styrax spp.), the growth and development of flower and fruit in the West and East of the same tree received a relatively the same amount of irradiation which was resulting in the same ratio of number of fruits/flowers $(\mathrm{P}>0.05)$ and the same size of fruit $(\mathrm{P}>$ 0.05) (Syamsuwida et al. 2014).

As an illustration of the reproductive potential of other species of forest plants, it is reported that pilang (Acacia leucophloea), weru (Albizia. procera) and mindi (Melia azedarach) produced PERS values of 19\%, 35\% and 34\% (Syamsuwida et al. 2011, Syamsuwida et al. 2012), respectively. Thus, $S$. grandiflora has reproductive potential that is almost the same as pilang, but in reality, pilang seedlings collected from trees or forest floors in National Park of West Bali (NPWB) are attacked by caterpillar pests for about 20-43\% (Suita et al. 2012). Viable seed production per tree from NPWB is greatly reduced if pest attacks are taken into account. So far, observations of $S$. grandiflora pods from NPWB, have not shown any significant pest attacks.

Sesbania grandiflora, as well as any other legumes in general, have hermaphrodite sexual organs, namely, in one flower there are male organs (stamen) and female organs 
(pistils). A common phenomenon of hermaphrodite plants is to produce a low fruit/flower ratio (Syamsuwida et al. 2014). In fact, fruit set is influenced by many factors related to reproductive biology, including pollination systems and flowering behavior. According to Syamsuwida et al. (2014), the formation of fruit in a low value is likely to occur due to lack of flower abundance, so that the pollination process is not optimal. Therefore, pollination will be in optimum if it occurs in the peak flowering season. In addition, the availability of pollen sources is also limited because of the low density of flowering plants so that pollination efficiency is reduced (Heghland. 2014). Abundant flowering will attract pollinating insects to visit flowers. besides the availability of pollen resources is also an important factor in fruit production (Cuevas et al. 2014). In addition, individual flowers in large trees are likely to be surrounded by flowering with the same genetic makeup, consequently, the proportion of geitonogamy pollination (pollen comes from other flowers of the same plant) is greater, thus increasing the risk of self-generated zygotic and decrease the suitability of parents through inbreeding depression.

Another factor that influences fruit production related to the characteristics of flowers is the maturity of their sexual organs. There are very few reports reported on the suitability between pollen $(\delta)$ and stigma receptivity ( $(+)$. Most studied species were described as dichogamous with pollen release and stigma receptivity temporally isolated within the flower (Silva et al. 2015). In this case, it is necessary to take the mature pollen first to be stored in optimum conditions, then pollens are pollinated on the surface of stigma when receptive. Protandry flowers are likely to be one of the causes of low reproductive potential which results in low fruit production.

It is concluded that the development cycle of flowering and fruiting of $S$. grandiflora at Cibinong, Bogor, lasts for 3-4 months beginning with the emergence of generative buds in April and developing into flower shoots in the same month. Flowers bloom (anthesis) in May, developing into young fruit in June. Harvesting of ripe fruit can be done in June-July. The reproductive potential of $S$. grandiflora is generally categorized as low, with the fruit set value (fruit/flower ratio) and seed set (seed/ovule ratio) respectively between $12-24 \%$ and $71-99 \%$. The proportion of ovules that were successfully pollinated and developed into viable seeds (PERS) ranged between 11-23\%. Reproductive variables of $S$. grandiflora in the eastern and western branches did not show significant differences $(\mathrm{P}\rangle$ $0.05)$, except for the number of fruits $(\mathrm{P}<0.05)$.

\section{ACKNOWLEDGEMENTS}

The authors are grateful to the owner of $S$. grandiflora (turi) stand at Cibinong Sub-district, Bogor District, West Java, Indonesia which has allowed us to use S. grandiflora plantation for observation. High appreciation is also addressed to the technician staff for their assisting during observation.

\section{REFERENCES}

Ariyanti E. 2018. Pengaruh perubahan iklim terhadap produksi buah durian (Durio zibethinus) pada sistem agroforestri di Desa Pappandangan Kecamatana Anreapi Polewali Mandar. [Hon. Thesis]. Universitas Hasanudin, Makassar. [Indonesian].

Ashari H, Hanif Z, Supriyanto A. 2014. Kajian dampak iklim ekstrim curah hujan tinggi (La-Nina) pada jeruk siam (Citrus nobilis var. Microcarpa) di Kabupaten Banyuwangi, Jember dan Lumajang. Planta Tropika Journal of Agro Science. 2 (1): 49-55 [Indonesian].

Brown CJ, O'Connor M, Poloczanska ES, Schoeman DS, Buckley LB, Burrows MT, Duarte CM, Halpern BS, Pandolfi JM, Parmesan C, Richardson AJ. 2016. Ecological and methodological drivers of species'distribution and phenology responses to climate change. Global Ch Biol 22: 1548-560.

Cardoso FCG, Zwiener VP, Marques MCM. 2019. Tree phenology along a successional gradient of tropical Atlantic Forest. J Plant Ecol 12 (2): 272-280.

Cleland EE, Allen JM, Crimmins TM, Dunne JA, Pau S, Travers SE, Zavaleta ES and Wolkovich EM. 2012. Phenological tracking enables positive species responses to climate change. Ecology 93 (8):17651771

Cuevas E, Jimenez R, Mikel LM. 2014. Sex-specific reproductive components and pollination ecology in the subdioecious shrub Fuchsia microphylla. Plant Biol (Stuttg) 16 (6): 1096-1103.

Dharmawati FD, Syamsuwida D, Aminah A. 2016. Pola pembungaan dan pembuahan akor (Acacia auriculiformis) di Parungpanjang-Bogor. Jurnal Perbenihan Tanaman Hutan 4 (1): 43-52. [Indonesian]

Fauzi AA, Sutari W, Nursuhud, Mubarok S. 2017. Faktor yang mempengaruhi pembungaan pada mangga (Mangifera indica L.) Jurnal Kultivasi 16 (3): 461-465. [Indonesian]

Hegland SJ. 2014. Floral neighbourhood effects on pollination success in red clover are scale-dependent. Function Ecol 11. DOI: 10.1111/1365-2435.12223.

Kimball KD, Davis ML, Weihrauch DM, Murray GLD, Rancourt K. 2014. Limited alpine climatic warming and modeled phenology advancement for three alpine species in the Northeast United States. Am J Bot 101 ( 9 ): 1437-1446.

Koeslulat EE, Prayitno TA, Sutapa JPG, Irawati D. 2016. Karakteristik energi tiga jenis pohon cepat tumbuh pada tiga kelas diameter. Jurnal Agroforestry 11 (6): 23-31. [Indonesian]

Kutschera U, Briggs WR. 2016. Phototropic solar tracking in sunflower plants: an integrative perspective. Ann Bot 117 (1): 1-8.

Owens JN, Sornsathaporhkul P, Mitchareon ST. 1991. Studying Flowering and Seed Ontogeny in Tropical Forest Trees. ASEANCanada Forest Tree Seed Centre and Royal Forest Depart, Thailand.

Pramono AA, Syamsuwida D, Djam'an DF. 2017. Produksi buah dan benih mahoni (Swietenia macrophylla) di Parung Panjang dan Jonggol (Bogor, Jawa Barat) serta kaitannya dengan status kesuburan tanah. Prosiding Seminar Nasional Masyarakat Biodiversitas Indonesia 3 (3): 381-389. [Indonesian].

Putri KP, Syamsuwida D, Kurniaty R, Suita E, Djam'an DF. 2015. Peran perbenihan dalam peningkatan produktivitas hutan penghasil energi dan obat-obatan di Propinsi Lampung. In: Nina M, Yulianti B, Agus AP, Mamat R, Dede JS (eds.) Seminar Hasil Penelitian Balai Penelitian Teknologi Perbenihan Tanaman Hutan dan Balai Penelitian Kehutanan Palembang; Prosiding Seminar Teknologi Perbenihan, Silvikultur dan Kelembagaan dalam Peningkatan Produktivitas Hutan dan Lahan, Bandar Lampung, 11 Agustus 2015. [Indonesian]

Ruminta. 2015. Dampak Perubahan Iklim terhadap Produksi Apel di Batu Malang. Jurnal Kultivasi 14 (2): 42-48. [Indonesian]

Sarvina Y, Sari K. 2017. Dampak ENSO terhadap Produksi dan Puncak Panen Durian di Indonesia. Jurnal Tanah dan Iklim 41 (1): 147-155. [Indonesian]

Silva AV, Coelho VPM, Ventrella MC, Vieira MF. 2015. Timing of pollen release and stigma receptivity period of Piper vicosanum: New insights into sexual reproduction of the genus. Am J Bot 102 (4): 626633.

Suita E, Suhartati T, Haryadi D. Abay. 2012. Pengujian mutu fisikfisiologis dan pendugaan umur simpan benih jenis weru (Albizia procera) dan pilang (Acacia leucophloea). Laporan Hasil Penelitian. Balai Penelitian Teknologi Perbenihan Tanaman Hutan Bogor. [Indonesian] 
Sunu P dan Wartoyo. 2006. Dasar hortikultura. Jurusan/program studi Agronomi. Fak.Pertanian, Universitas Sebelas Maret, Surakarta. [Indonesian]

Switanek M, Clairsheim K, Truhetz H, Brodschneider R. 2017. Modelling seasonal effects of temperature and precipitation on honey bee winter mortality in a temperate climate. Sci Tot Environ 579: 1581-1587.

Syamsuwida D, Aminah A, Muharam A. 2011. Fenologi dan Potensi Produksi Benih Tanaman Penghasil Kayu Energi Jenis Weru (Albizia procera), pilang (Acacia leucophloea), akor (Acacia auriculiformis) dan kaliandra (Caliandra callothyrsus). Laporan Hasil Penelitian. Balai Penelitian Teknologi Perbenihan, Bogor. [Indonesian]

Syamsuwida D, Aminah A, Nurochman N, Sumarni EB, Ginting J. 2014. Siklus perkembangan pembungaan dan pembuahan serta pembentukan buah kemenyan (Styrax benzoin) di Aek Nauli. Jurnal Penelitian Hutan Tanaman 11 (2): 89-98. [Indonesian].

Syamsuwida D, Indrawan A, Palupi ER, Siregar IZ. 2012. Flower initiation, morphology and developmental stage of flowering-fruiting of Melia azedarach L. Journal Manajemen Hutan Tropika 5 (1):10-17 [Indonesian].

Wiens D, Calvin CL, Wilson CA, Davern CI, Frank D, Seavey SR. 1987. Reproductive success, spontaneous embryo abortion and genetic load in flowering plants. Oecologia 71:501-509.

Wiraatmaja IW. 2017. Suhu, Energi Matahari dan Air dalam Hubungan dengan Tanaman. Universitas Udayana, Denpasar, Bali. [Indonesian] 